\title{
A MULTI-CRITERIA FRAMEWORK FOR OFFICE TENANTS' PREFERENCES AT OFFICE BUILDINGS
}

\author{
Yasmin Mohd ADNAN ${ }^{\text {a,* }}$, Md Nasir DAUD ${ }^{\text {a, }}$ Muhammad Najib MOHAMED RAZALI ${ }^{b}$ \\ ${ }^{a}$ Department of Estate Management, Faculty of Built Environment, University of Malaya, 50603 Kuala \\ Lumpur, Malaysia \\ ${ }^{b}$ Department of Real Estate, Faculty of Geoinformation and Real Estate, Universiti Teknologi Malaysia, \\ 81310 Johor Bahru, Malaysia
}

Received 1 June 2013; accepted 4 June 2014

\begin{abstract}
In order to mitigate the anticipated oversupply of office space, it is necessary to gauge the preference of office occupiers, namely tenants of purpose built office buildings, since these tenants form the indicator of demand for space. In this study, a multi-criteria decision making method (MCDM) the Analytic Hierarchy Process (AHP) procedure was employed to analyse the relative importance of the main factors chosen by the main sectors of tenants at top grade office buildings in Kuala Lumpur city centre. This study had identified the elicitation of experts' opinion and tenants' selection comprises twenty-six important factors for office occupation in Kuala Lumpur city centre, grouped under four main categories: Location, Lease, Building and Financial/Cost. This study then employed AHP to assess the relative importance placed on each category, revealing the varying patterns of preferences when tested on tenants from three main business sectors occupying top grade office buildings. The findings showed that, between the three sectors (Finance/Banking, ICT \& Media and Oil \& Gas), differences in preference were only slight for most factors but were significant for a few. The findings from this study are insightful in informing decisions on future office provision, particularly in the context of working towards satisfying office tenants' requirements.
\end{abstract}

KEYWORDS: Analytic Hierarchy Process; Office buildings; Preference; Tenants; Kuala Lumpur

\section{INTRODUCTION}

This paper reports on a study that has employed the Analytic Hierarchical Processing (AHP) framework to examine tenants' perspectives with regard to their preferred office space within the city centre of Kuala Lumpur. In a market where office space faces an oversupply and a decentralisation to the suburbs, tenants have greater choices with office types and locations. There is pressure in the competition as excess office space affords tenants greater selectivity in their occupation decisions. As such, owners' knowledge of the factors that influence office occupiers' decisions becomes important for office space marketing. Establishing what factors constitute tenants' requirements in their office occupation decisions would assist office space providers, managers and marketing agents towards meeting those requirements. For Kuala Lumpur, where the office space occupancy rate had fallen to

\footnotetext{
* Corresponding author. E-mail: yasminma81@gmail.com
}

$75 \%$ by the fourth quarter of 2012 (NAPIC 2013), the challenge has become even more critical for the office space stakeholders. Thus the study aims to inform these stakeholders on factors that the demand side views as important to its consideration of office space.

The earlier studies by several authors have identified factors important to office space tenants in Kuala Lumpur, but from a more general perspective. This had involved an elicitation of the opinions of experts, leading to the identification of sixty factors of influence grouped under four main categories: Location, Lease, Building and Financial/Cost. Furthermore, the tenants from top-grade offices in Kuala Lumpur were asked to assess the importance of each factor. Previous studies had refined factor selection to twenty-six from the sixty previously identified by researchers. With the smaller number of factors that were obtained, Analytic Hierarchy Process (AHP) was employed 
to examine the relative importance of each factor involved, a study that forms the subject of this paper. In many ways, this current study is repetitive of the work that precedes it, but with two changes being introduced apart from the fact that the number of factors is reduced this time. First, the investigation is narrowed to three main tenant sectors only (as opposed to all sectors before), and second, AHP is used. The three main tenant sectors are the Finance/Banking, ICT \& Media, and Oil \& Gas. As an approach, AHP is proven for its ability to reveal a customer's preference (Helm et al. 2008).

\section{Kuala Lumpur city centre}

Kuala Lumpur currently accommodates the single largest concentration of office buildings in Malaysia, having 338 office buildings within its city centre (NAPIC 2013). A stated primary goal for Kuala Lumpur is to enhance it as an international commercial and financial centre (Kuala Lumpur Structure Plan 2020). Following a public announcement in 2010 to redevelop Greater Kuala Lumpur into a world class city in line with a key strategy under the Economic Transformation Programme (ETP), the City is headed for a major expansion on the supply side over the next twenty years with the planned addition of approximately 8.4 million square metres (90 million square feet) to stock of office space. The plan includes the 100-storey Warisan Merdeka to be constructed as an iconic office development in the city centre area.

The office market in Kuala Lumpur has shown trends of increase in supply. By the fourth quarter of 2012, the stock of office space in Kuala Lumpur had stood at 7.1 million square metres, while occupancy rate averaged $75 \%$ (NAPIC 2013). This occupancy rate features a decline from the $80 \%$ average recorded for the period of 2008-2010.

\section{Performance of office markets in Kuala Lumpur city centre}

The demand for office space is indicated by its occupancy and take-up rates. In Kuala Lumpur, office space performance has manifested a sign of oversupply during more recent times. At its peak, occupancy rate achieved $98.1 \%$ in 1997 . This failed to sustain as the rate took a sharp dive to around $82 \%$ one year later when a massive new supply was met by a sharp decline in the take-up due to the onset of the financial crisis. Up until now, a repeat of the 1997 performance has yet to be seen. During the period of 2008 to 2010, occupancy only hovered around $80 \%$ as the economy hit the doldrums. Against this backdrop, the 2010 announcement triggered concern about the ability of the take up to cope with the ballooning supply and raised the spectre of office occupancy rate falling to an unprecedented level. The proposed projects, if materialised, would add 8.8 million square metres of commercial space to the city centre, a significant portion of which will constitute new offices (see Table 1).

It would appear conceivable that the office sector is headed towards a very competitive market environment. For the individual building owners, they will be better prepared to meet the challenge if they obtain insight into what office tenants look for. Further, the data on what tenants consider influential to their office occupation decisions will benefit the formulation of office supply strategies or policies that aim to make Kuala Lumpur a major draw among firms and organisations, particularly the multinational corporations. These are areas in which the study expects to contribute.

Table 1. The commercial projects planned within Kuala Lumpur city centre

\begin{tabular}{|c|c|c|c|c|c|c|}
\hline Location/site & Project name & Developer & $\begin{array}{l}\text { Land area } \\
\text { (acres) }\end{array}$ & $\begin{array}{l}\text { Project cost } \\
\text { (as announced) }\end{array}$ & $\begin{array}{l}\text { Possible total } \\
\text { gross floor area }\end{array}$ & $\begin{array}{l}\text { Likely development } \\
\text { period }\end{array}$ \\
\hline $\begin{array}{l}\text { Bukit Bintang } \\
\text { East }\end{array}$ & $\begin{array}{l}\text { Kuala Lumpur } \\
\text { International } \\
\text { Financial District } \\
\text { (KLIFD) }\end{array}$ & $\begin{array}{l}\text { Malaysia- } \\
\text { Mudabala } \\
\text { Development }\end{array}$ & 85 & $\begin{array}{l}\text { Over RM15 } \\
\text { Billion }\end{array}$ & $\begin{array}{l}\text { Over } 1.86 \text { Million } \\
\text { sq. m ( } 20 \text { Million } \\
\text { sq. ft.) }\end{array}$ & $15-20$ years \\
\hline $\begin{array}{l}\text { Kampung } \\
\text { Baru }\end{array}$ & $\begin{array}{l}\text { Yet } \\
\text { unnamed }\end{array}$ & $\begin{array}{l}\text { Kg Baru De- } \\
\text { velopment } \\
\text { Corporation }\end{array}$ & 233 & Not Reported & $\begin{array}{l}\text { Over } 5.57 \text { Million } \\
\text { sq. m ( } 60 \text { Million } \\
\text { sq. ft.) }\end{array}$ & $\begin{array}{l}\text { As yet, undetermi- } \\
\text { nable }\end{array}$ \\
\hline $\begin{array}{l}\text { Jalan Hang } \\
\text { Tuah }\end{array}$ & Warisan Merdeka & PNB & 55 & $\begin{array}{l}\text { Over RM3 Bil- } \\
\text { lion }\end{array}$ & $\begin{array}{l}\text { Over } 0.93 \text { Million } \\
\text { sq. m (10 Million } \\
\text { sq. ft.) }\end{array}$ & $10-12$ years \\
\hline Pudu Jail Site & $\begin{array}{l}\text { Bukit Bintang } \\
\text { Commercial Cen- } \\
\text { tre }\end{array}$ & UDA & 20 & $\begin{array}{l}\text { Over RM } 5 \\
\text { Billion }\end{array}$ & $\begin{array}{l}\text { Over } 0.46 \text { Million } \\
\text { sq. m ( } 5 \text { Million } \\
\text { sq. ft.) }\end{array}$ & $15-20$ years \\
\hline
\end{tabular}

Source: WTW Property Market (2011). 


\section{LITERATURE REVIEW}

\section{Factors influencing office occupation}

The literature regarding this subject is very limited. These include Abel (1994), Mills (1992), Bollinger et al. (1998), Dunse and Jones (1998, 2002), Dunse et al. (2001), Gibson and Lizieri (2001), Sing (2005), Sing et al. (2004, 2006) and Ho et al. (2005), all of which were not so recent. A more recent and similar observation was made by Leishman et al. (2012). Previous research, nevertheless, have contributed meaningfully toward clarifying factors that influence office occupation decisions. They have identified location, architectural design quality, physical attributes of buildings, and partial determinants of rent as the main factors. Based on relevant previous research, factors specific to Kuala Lumpur through an experts' survey were identified from the findings by Adnan and Daud (2010) followed by a tenant survey (Adnan et al. 2012) as already reported earlier.

\section{Office preference measurement}

The preference measurement for an existing and new product requires gauging customers' needs at different levels of decision-making. As such, the numerous arrays of attributes of an office space may lead to the difficulty of assessing the most suitable tenant for an available office space.

There are many categories of tenant organisations occupying the office space at Kuala Lumpur city centre. A survey in early 2010 of tenants' organisations in sixty-one top grade office buildings found that the three main categories of organisations (as classified by the Malaysian Standard Industrial Classification (MSIC) 2008 are: Banking \& Finance, Oil \& Gas, and ICT \& Media. These three categories of organisations together occupy approximately $40 \%$ of the space taken up by tenant occupants at the buildings in the sample. It has been observed that Banking/Financial Services have the highest percentage of occupied office space among the service sectors.

As office spaces in various office buildings across the city centre of Kuala Lumpur vary in their attributes, knowledge of the different combination of factors forming tenants' preferences would assist building owners/managers in matching those preferences to office space within the best available option. However, analysing tenants' preferences in terms of a multitude of defined criteria would be difficult to handle manually due to the limitation of the human brain (March, Simon 1958; Argote,
Greve 2007). Thus, an assessment tool is needed to aid the decision making by performing the preference analyses of the factors for office space within the top grade office buildings in the study area. This is especially useful to gauge the preferences of the top three tenant sectors that occupy a large percentage of the office space in Kuala Lumpur.

\section{USE OF AHP FOR OFFICE PREFERENCE MEASUREMENT}

Tenants' preferences for office space reflect the preferences of the consumers for a product. In terms of the technique for gauging preferences, although conjoint analysis (CA) has emerged as most commonly employed in earlier studies particularly in marketing studies, more recent works by Koo and Koo (2010) and Helm et al. (2008) have found that other tools are also useful, including the Analytic Hierarchy Process (AHP) technique. In fact, Koo H. Y. and Koo L. C. (2010) and Helm et al. (2008) have shown the advantages of AHP over $\mathrm{CA}$, with the most significant advantage being that while CA is a better choice in relatively simple decision problems, AHP is a better method in more complex problems (Helm et al. 2004, 2008).

The AHP was pioneered and refined by Saaty (1980, 1994). It aims to quantify relative priorities for a given set of alternatives on a ratio scale based on the judgement of the decision maker. It also stresses the importance of the intuitive judgements of a decision maker as well as the consistency of the comparisons of the alternatives in the decision making process (Saaty 1980; Saaty, Vargas 2012). For decision problems that involve a large number of attributes, AHP is particularly useful since its hierarchical structuring of objectives makes assessment of factor weights easier. This makes the technique particularly useful in this study to assess weights for the criteria preference in office selection.

In this technique, the problem is deconstructed into a hierarchy to include all attributes. The three main principles used in AHP (Forman, Selly 2000; Forman, Gass 2001; Saaty, Vargas 2012) are:

(i) decomposition of a complex multi-criteria problem into a structure;

(ii) comparative judgements of alternatives using criteria within the structure; and

(iii) synthesis of the judgements to arrive at overall priorities, preferences or preferred actions. 
Saaty (1990) proposed the method to model dynamic judgment in the AHP, that is, by expressing the elements of the pairwise comparison matrix as follows:

$\mathrm{A}=\left[a_{i j}\right]=\left[\begin{array}{cccc}\mathrm{C}_{1} & \mathrm{C}_{2} & & \mathrm{C}_{\mathrm{n}} \\ \mathrm{C}_{1} & a 12 & \cdots & a 1 n \\ & \vdots & & \vdots \\ \frac{1}{\mathrm{C}_{2}} & 1 & \cdots & a 2 n \\ \vdots & \vdots & & \vdots \\ \vdots & \vdots & & : \\ 1 & \frac{1}{a 2 n} & & 1\end{array}\right]$,

$\sum_{i=1}^{n} a_{i j}=\mathrm{A} \ldots \ldots \ldots \ldots \ldots . . . . . . .$. the sum is equal to one.

AHP consists of three main operations including hierarchy construction, priority analysis and consistency verification. First, the decision maker needs to break down complex multi-criteria decision problems into their component parts, for which every possible attribute is arranged into multi hierarchical levels. Thereafter, the decision maker has to compare each cluster in the same level in a pair-wise fashion based on his own experience and knowledge. Since the comparisons are carried out through personal or subjective judgements, some degree of inconsistency may arise. To guarantee the judgements are consistent, the final operation, called consistency verification (regarded as one of the greatest advantages of the AHP), is applied to measure the degree of consistency among pair-wise comparisons by computing the consistency ratio (Anderson et al. 2005).

The AHP has been used to analyse property decisions that involve several criteria, some of which are qualitative or subjective. These include weighing the subjective attributes of housing environment and choices (Wu 2010; Li 2009), the locational qualities that influence housing preferences (Kauko 2003, 2006, 2007), qualitative building features that attract office occupants (Ho et al. 2005), assessing the importance of factors influencing hotel investment decision making (Newell, Seabrook 2006), and harnessing real estate investment decision through proper tenant selection (Olawande 2011).

In the current study, views on the importance of the office space attributes (identified through factors determined earlier) in pair-wise comparisons were elicited from tenants in three major sectors currently occupying office buildings in the city centre of Kuala Lumpur. As mentioned by Cheng and Li (2002), AHP method may be practical for large samples as "cold-called" respondents may have a high tendency to provide arbitrary answers, resulting in a high degree of inconsistency. Thus, a total of sixty companies were selected comprising the three respective tenants' organisation groups. Twenty organisations' personnel responsible for the office occupation decision from each tenant sector were chosen. A comparison was then made of tenants' office space preferences across three main sectors of tenant organisations, i.e., Banking/Finance, ICT \& Media and Oil \& Gas. To make an assessment of how preferences differ across the three tenants sectors, the relative means and ranks of weights were compared. The mean statistic offers an advantage since it enables further statistical tests such as $t$-test, analysis of variance (ANOVA) and multiple comparison procedures to be performed. Thus, the assessment of means and ranks of the different tenants' profiles can be based on the difference in mean weights. A summary of the hierarchical structure of the main categories and factors identified for the AHP operation is shown in Figure 1.

\section{RESULTS AND DISCUSSION}

Twenty-eight tenants from the three categories of tenants' groups (Finance/Banking, ICT \& Media and Oil \& Gas) responded to the survey; ten of which from the Finance/Banking sector and nine each from the other two sectors. From each respondent, data in the form of pair-wise judgment matrix was obtained. The measurement and data collection phases were combined using the geometric mean approach at each hierarchy level to obtain the corresponding consensus pair-wise comparison judgement matrices. In this study, the sub-critera weights refer to global weights. The normalised local priority weights of the main and sub-critera (identified earlier as the main categories of Location, Financial/Cost, Lease and Building, and twenty-six sub-critera also known as factors under these main categories) which have been obtained were combined with respect to all successive hierarchical levels. Thus we could obtain the global composite priority weights of all criteria and subcritera used in the AHP model. The tenant sectors preference for each of the sub-criterion can be observed through the global priority weights as shown in Table 2. The mean of the weights generated from each group have been used to represent the weight for the sub-critera as perceived by the respective group. The comparison of the ranking for each sub-criterion forming the indication of the preference of the office space attributes between the three tenant groups is shown in Figure 2. 


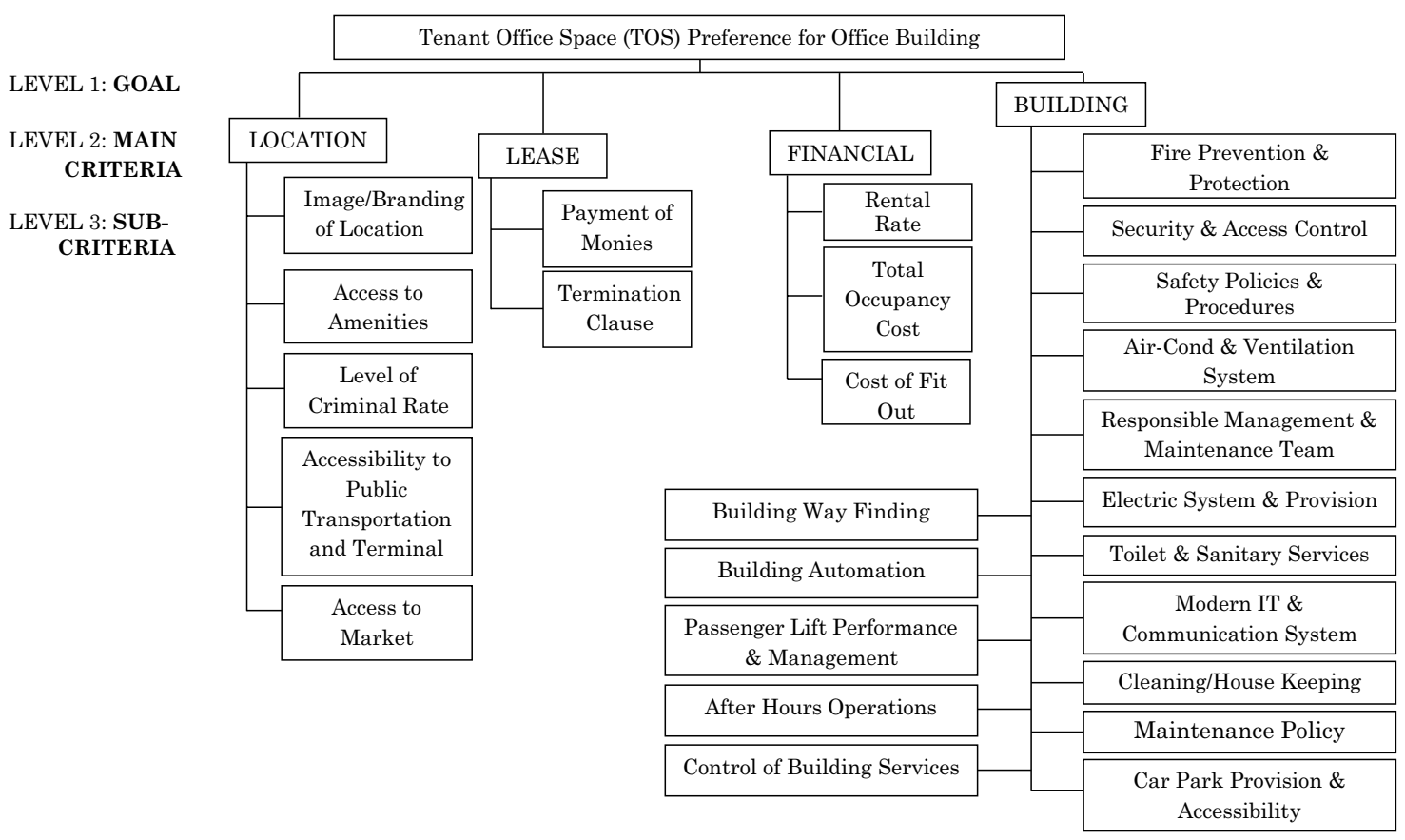

Fig. 1. Office space preference hierarchy framework

Table 2. Overall and group mean sub criteria weights

\begin{tabular}{|c|c|c|c|c|c|}
\hline \multirow[t]{2}{*}{ Main criteria } & \multirow[t]{2}{*}{ Sub criteria/factors } & \multicolumn{3}{|c|}{ Group mean weight } & \multirow{2}{*}{$\begin{array}{l}\text { Overall } \\
\text { mean weight }\end{array}$} \\
\hline & & $\begin{array}{l}\text { Finance } \\
(\mathrm{n}=10)\end{array}$ & $\begin{array}{l}\text { ICT \& Media } \\
(\mathrm{n}=9)\end{array}$ & $\begin{array}{l}\text { Oil \& Gas } \\
(\mathrm{n}=9)\end{array}$ & \\
\hline \multirow[t]{4}{*}{ Location } & Branding image & 6.71 & 6.52 & 2.63 & 5.28 \\
\hline & Access to market & 7.84 & 3.60 & 3.72 & 5.05 \\
\hline & Access to amenities & 5.55 & 3.86 & 6.38 & 5.26 \\
\hline & $\begin{array}{l}\text { Access to public transportation \& } \\
\text { terminal }\end{array}$ & 6.26 & 3.35 & 8.25 & 5.95 \\
\hline \multirow[t]{3}{*}{ Lease } & Level of criminal rate & 5.98 & 7.07 & 7.27 & 6.77 \\
\hline & Termination clause & 5.51 & 4.83 & 3.36 & 4.56 \\
\hline & Payment of monies & 3.18 & 6.44 & 5.44 & 5.02 \\
\hline \multirow[t]{16}{*}{ Building } & Security and access control & 2.28 & 2.42 & 2.13 & 2.27 \\
\hline & $\begin{array}{l}\text { Responsible management \& } \\
\text { management team }\end{array}$ & 3.11 & 3.01 & 2.61 & 2.91 \\
\hline & Maintenance policy & 3.24 & 1.64 & 1.98 & 2.28 \\
\hline & Cleaning/housekeeping & 1.81 & 1.47 & 1.60 & 1.62 \\
\hline & Safety policies and procedures & 2.77 & 1.92 & 2.72 & 2.47 \\
\hline & Fire prevention \& protection & 2.62 & 3.28 & 3.12 & 3.00 \\
\hline & After hours operations & 1.54 & 1.74 & 2.27 & 1.85 \\
\hline & Toilet sanitary \& fittings & 2.04 & 3.84 & 1.85 & 2.57 \\
\hline & Air conditioning \& ventilation & 2.21 & 2.27 & 2.85 & 1.78 \\
\hline & Electrical system \& provision & 2.28 & 2.77 & 2.80 & 2.61 \\
\hline & Modern IT \& telecommunication & 2.17 & 4.83 & 2.97 & 3.32 \\
\hline & Building automation \& EMS & 1.58 & 2.44 & 2.50 & 2.17 \\
\hline & Control of building services & 1.72 & 2.06 & 2.40 & 2.06 \\
\hline & Passenger lifts performance \& control & 1.97 & 2.16 & 3.57 & 2.56 \\
\hline & Car park provision \& accessibility & 2.06 & 2.74 & 2.68 & 2.49 \\
\hline & Building way finding & 1.49 & 2.07 & 2.30 & 1.95 \\
\hline \multirow[t]{3}{*}{ Financial/cost } & Rental rate & 9.91 & 8.81 & 8.40 & 9.04 \\
\hline & Cost of fit out & 5.19 & 5.95 & 4.46 & 5.20 \\
\hline & Total occupancy cost & 9.01 & 8.68 & 9.13 & 8.94 \\
\hline
\end{tabular}




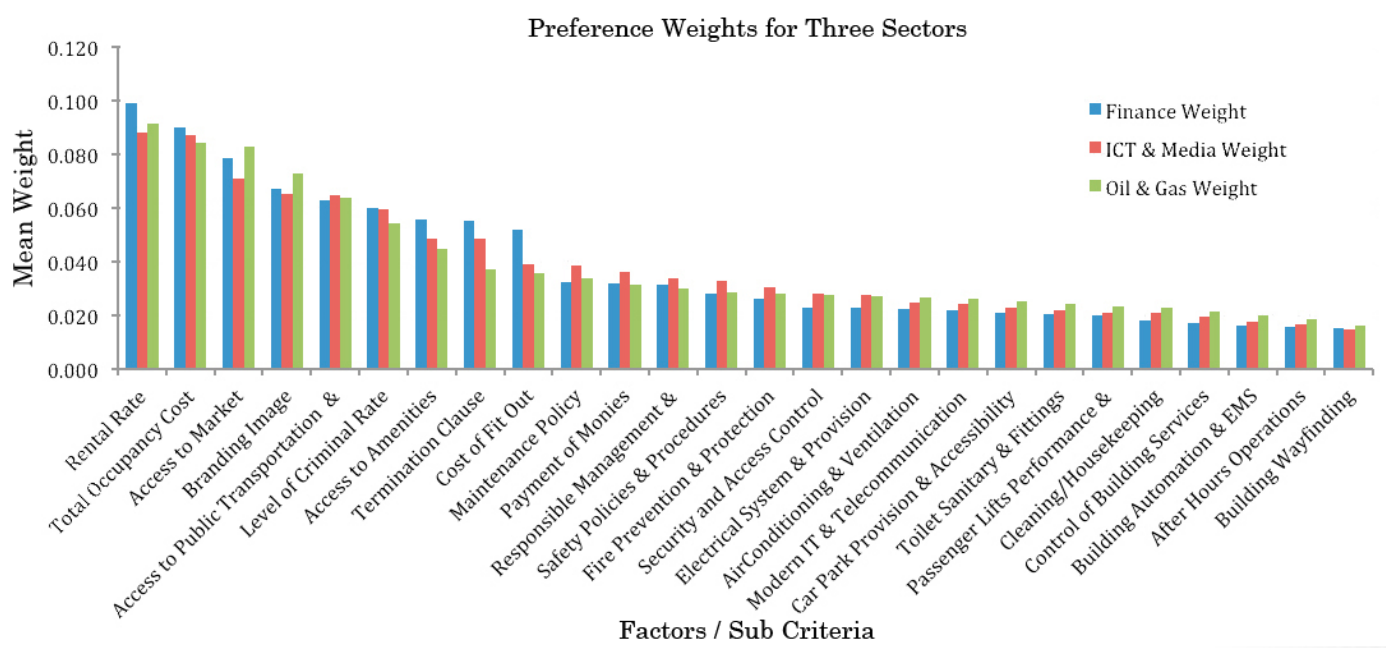

Fig. 2. Overall preference weights between the three sectors

The results show that, in terms of the global weights for all categories of tenants, "rental" and "occupancy costs" score as the top two weights (9.1\% and $8.9 \%$ respectively). "Afterhours operations" and "cleaning/housekeeping" score as the bottom two weights (1.8\% and $1.6 \%$ respectively). The next top weights fall on the criteria under "Location" and "Lease" while the next bottom weights fall on the sub-criteria under "Building". In terms of the ranking among the 26 sub-criteria, those grouped under "Financial" were the most important (ranked $1^{\text {st }}$, $2^{\text {nd }}$ and $8^{\text {th }}$ ) followed by the ones under "Location" (ranked $3^{\text {rd }}, 4^{\text {th }}, 5^{\text {th }}, 6^{\text {th }}$ and $7^{\text {th }}$ ). These sub-criteria account for eight out of ten sub-criteria at the top, with the other two namely "payment of monies" and "termination clause" coming from "Lease". No subcriterion under "Building" attained a spot in the top ten. This shows that "Financial/Cost" commands the highest preference among the tenants followed by "Location" and "Lease". Sub-criteria under "Building", on the other hand, scored the lowest weights, indicating tenants' low preference towards them in the city centre of Kuala Lumpur. A probable explanation could be that tenants in this study glossed over the sub-criteria under "Building", choosing instead to focus on other sub-criteria since the buildings they occupy are already among the best available, with few issues physical or otherwise.

\section{Assessment of the criteria for office space occupation - three sectors (Finance/ Banking, ICT \& Media and Oil \& Gas) - global weights}

To determine how the different tenant sectors compare, a possible approach is to use ANOVA to perform a cross-sector comparison of the global weights for all the sub-criteria. However, since the number of respondents is too small to meet the conditions for ANOVA, a $t$-test was used whereby pair-wise comparisons were made among the three sectors; each testing for the statistical significance of the weight differences (Chua 2006). Since the Leverne Statistics for all data sets are not significant ( $>0.001$ ), the equality of variance and $t$-test analyses were undertaken. An assessment of the rank correlations between the ranks of the global weights was also carried out. This was to examine the consistency of the ranking of the sub-criteria among the three sectors of tenants.

"Finance" versus "ICT \& Media"

The Finance and ICT \& Media sector organisations differ in the importance they place on the top criteria. For example, the Finance organisations have assigned the top two weights on criteria that are financially related, i.e. "rental rate" and "total occupancy cost". They also have placed "building automation \& EMS", "after-hour operations" and "building wayfinding" as the three bottommost criteria. The ICT \& Media organisations have placed two of the "Financial/Cost" criteria in their top ten ranking ("rental rate" and "total occupancy cost"). Similar to the Finance sector organisations, the ICT \& Media sector has placed the first two subcriteria under the Financial/Cost criteria as the top ranked sub-criteria.

The statistics show a strong rank correlation between the Finance and ICT \& Media organisations. This suggests that the office occupation preferences between the two tenant organisation groups are highly similar. 


\section{Finance versus Oil \& Gas}

While the overall picture is that these two sectors are highly correlated, significant differences exist on a particular criterion, "passenger lift performance and control" under "Building" $(t$ score $=$ $2.141, \mathrm{df}=26, \mathrm{p}<0.05)$. A higher mean value accorded by the Oil \& Gas sector $($ mean $=3.57)$ as compared to the Finance sector (mean $=1.97$ ) reflects the differing levels of priority given by these two sectors on this particular criterion.

The two sectors differ on what they elect as the top criteria. While the Finance sector chose "rental rate", Oil \& Gas chose "total occupancy cost". Both criteria are nevertheless under "Financial/Cost". In terms of the ranking among the twenty-six criteria, the Finance sector has ranked the criteria under "Financial/Cost" as the two most important (1st and 2nd) followed by those under "Location" (ranked $3^{\text {rd }}, 4^{\text {th }}, 5^{\text {th }}, 6$ th and $7^{\text {th }}$ ); together they account for the top seven criteria.

Similarly the Oil \& Gas sector organisations have only two of the "Financial/Cost" sub-criteria in the top ten ranking. However, there are variations in the ranks of the top ten sub-criterion. The Oil \& Gas sector has placed "access to transportation", "level of criminal rate", "access to amenities" and "access to market" as the top ten sub-criterion under "Location" (ranked $3^{\text {rd }}, 4^{\text {th }}, 5^{\text {th }}$ and $8^{\text {th }}$ ).

In considering the two sectors' significant high rank correlation coefficient (rank correlation = $0.7032, \mathrm{p}=0.05)$, it is seen that there is a real correlation between the ranks of the Finance and Oil \& Gas organisations. It can be observed that although there is correlation, there are also differences in the preferences by these two sectors. The Oil and Gas sector has placed a significantly higher preference for "passenger lift capacity \& performance" than the Finance sector. However, these two sectors have also indicated similar preferences for the "Financial/Cost" and "Location" criteria.

\section{ICT \& Media vs Oil \& Gas organisations}

In considering the significant high rank correlation coefficient (rank correlation $=0.723, p=0.05$ ) of the two sectors, it is seen that there is a real correlation between the ranks of the criteria chosen by the ICT \& Media and Oil \& Gas organisations. While the two sectors' correlation is relatively high, there is a significant difference in their criteria priority for "access to public transportation \& terminal" under "Location" ( $t$ score $=2.418, \mathrm{df}=16, \mathrm{p}<0.05)$. The higher mean value for the Oil \& Gas sector organisations $($ mean $=8.25)$ reflects that they gave a higher priority to this sub-criteria than did the ICT \& Media sector organisations $($ mean $=3.35)$ for this sub-critera. When assessing the global weights of all the criteria of the two sectors of organisations, the two sectors have chosen the "Financial/Cost" criteria i.e. "rental rate" (8.8\%) as number one, while the Oil \& Gas organisations have chosen "total occupancy cost" (9.1\%).

In terms of ranking, among the 26 sub-criteria, the ICT \& Media sector have placed the "Financial/Cost" sub-criteria ("rental rate" and "total occupancy cost") as the two most important (ranked $1^{\text {st }}$ and $2^{\text {nd }}$ ), compared to "Location" sub-criteria (ranked $3^{\text {rd }}, 4^{\text {th }}$, and $9^{\text {th }}$ ), accounting for the top seven of the top ten sub-criteria. Similarly, the Oil \& Gas sector organisations have two of the "Financial/Cost" criteria in the top ten ranking. Thus it can be observed that these two sectors have similarly high preferences for the "Financial/Cost" criteria although the Oil \& Gas sector preferred the "access to public transportation \& terminal" than the ICT \& Media sector. The comparison of the weights and ranks of the sub-criteria among the three sectors are summarised in Table 3.

Table 3. Comparison of weights and ranks for each tenant sector of the sub criteria (global weight) in percentage (\%)

\begin{tabular}{|c|c|c|c|c|c|c|c|c|}
\hline \multirow[t]{2}{*}{ Rank } & \multicolumn{2}{|c|}{ All Three (3) sectors } & \multicolumn{2}{|l|}{ Finance } & \multicolumn{2}{|l|}{ ICT \& Media } & \multicolumn{2}{|l|}{ Oil \& Gas } \\
\hline & Sub criteria & Weight & Sub criteria & Weight & Sub criteria & Weight & Sub criteria & Weight \\
\hline 1 & Rental Rate & 9.1 & Rental Rate & 9.9 & Rental Rate & 8.8 & $\begin{array}{l}\text { Total Occupancy } \\
\text { Cost }\end{array}$ & 9.1 \\
\hline 2 & $\begin{array}{l}\text { Total Occupan- } \\
\text { cy Cost }\end{array}$ & 8.9 & $\begin{array}{l}\text { Total Occupan- } \\
\text { cy Cost }\end{array}$ & 9.0 & $\begin{array}{l}\text { Total Occupan- } \\
\text { cy Cost }\end{array}$ & 8.7 & Rental Rate & 8.4 \\
\hline 3 & $\begin{array}{l}\text { Level of Crimi- } \\
\text { nal Rate }\end{array}$ & 6.8 & $\begin{array}{l}\text { Access to Mar- } \\
\text { ket }\end{array}$ & 7.8 & $\begin{array}{l}\text { Level of Crimi- } \\
\text { nal Rate }\end{array}$ & 7.1 & $\begin{array}{l}\text { Access to Public } \\
\text { Transportation \& } \\
\text { Terminal }\end{array}$ & 8.3 \\
\hline 4 & $\begin{array}{l}\text { Access to Public } \\
\text { Transportation } \\
\text { \& Terminal }\end{array}$ & 6.0 & Branding/Image & 6.7 & Branding/Image & 6.5 & $\begin{array}{l}\text { Level of Criminal } \\
\text { Rate }\end{array}$ & 7.3 \\
\hline 5 & Branding/Image & 5.3 & $\begin{array}{l}\text { Access to Public } \\
\text { Transporta- } \\
\text { tion \& Terminal }\end{array}$ & 6.3 & $\begin{array}{l}\text { Payment of } \\
\text { Monies }\end{array}$ & 6.4 & $\begin{array}{l}\text { Access to Ameni- } \\
\text { ties }\end{array}$ & ntinued) \\
\hline
\end{tabular}




\begin{tabular}{|c|c|c|c|c|c|c|c|c|}
\hline \multirow[t]{2}{*}{ Rank } & \multicolumn{2}{|c|}{ All Three (3) sectors } & \multicolumn{2}{|l|}{ Finance } & \multicolumn{2}{|l|}{ ICT \& Media } & \multicolumn{2}{|l|}{ Oil \& Gas } \\
\hline & Sub criteria & Weight & Sub criteria & Weight & Sub criteria & Weight & Sub criteria & Weight \\
\hline \multicolumn{9}{|c|}{ (Continued) } \\
\hline 6 & $\begin{array}{l}\text { Access to Amen- } \\
\text { ities }\end{array}$ & 5.3 & $\begin{array}{l}\text { Level of Crimi- } \\
\text { nal Rate }\end{array}$ & 6.0 & Cost of Fit Out & 6.0 & $\begin{array}{l}\text { Payment of Mon- } \\
\text { ies }\end{array}$ & 5.4 \\
\hline 7 & $\begin{array}{l}\text { Access to Mar- } \\
\text { ket }\end{array}$ & 5.2 & $\begin{array}{l}\text { Access to Amen- } \\
\text { ities }\end{array}$ & 5.6 & $\begin{array}{l}\text { Termination } \\
\text { Clause }\end{array}$ & 4.8 & Cost of Fit Out & 4.5 \\
\hline 8 & Cost of Fit Out & 5.2 & $\begin{array}{l}\text { Termination } \\
\text { Clause }\end{array}$ & 5.5 & $\begin{array}{l}\text { Modern IT \& } \\
\text { Telecommunica- } \\
\text { tion Systems }\end{array}$ & 4.8 & Access to Market & 3.7 \\
\hline 9 & $\begin{array}{l}\text { Payment of } \\
\text { Monies }\end{array}$ & 4.9 & Cost of Fit Out & 5.2 & $\begin{array}{l}\text { Access to Amen- } \\
\text { ities }\end{array}$ & 3.9 & $\begin{array}{l}\text { Passenger Lifts } \\
\text { Performance \& } \\
\text { Control }\end{array}$ & 3.6 \\
\hline 10 & $\begin{array}{l}\text { Termination } \\
\text { Clause }\end{array}$ & 4.8 & $\begin{array}{l}\text { Maintenance } \\
\text { Policy }\end{array}$ & 3.2 & $\begin{array}{l}\text { Toilet Sani- } \\
\text { tary \& Fittings }\end{array}$ & 3.8 & $\begin{array}{l}\text { Termination } \\
\text { Clause }\end{array}$ & 3.4 \\
\hline 11 & $\begin{array}{l}\text { Modern IT \& } \\
\text { Telecommunica- } \\
\text { tion System }\end{array}$ & 3.3 & $\begin{array}{l}\text { Payment of } \\
\text { Monies }\end{array}$ & 3.2 & $\begin{array}{l}\text { Access to Mar- } \\
\text { ket }\end{array}$ & 3.6 & $\begin{array}{l}\text { Fire Preven- } \\
\text { tion \& Protection }\end{array}$ & 3.1 \\
\hline 12 & $\begin{array}{l}\text { Fire Preven- } \\
\text { tion \& Protec- } \\
\text { tion }\end{array}$ & 3.0 & $\begin{array}{l}\text { Responsible } \\
\text { Management \& } \\
\text { Maintenance } \\
\text { Team }\end{array}$ & 3.1 & $\begin{array}{l}\text { Access to Public } \\
\text { Transporta- } \\
\text { tion \& Terminal }\end{array}$ & 3.4 & $\begin{array}{l}\text { Modern IT \& Tel- } \\
\text { ecommunication } \\
\text { Systems }\end{array}$ & 3.0 \\
\hline 13 & $\begin{array}{l}\text { Responsible } \\
\text { Management \& } \\
\text { Maintenance } \\
\text { Team }\end{array}$ & 2.9 & $\begin{array}{l}\text { Safety Poli- } \\
\text { cies \& Proce- } \\
\text { dures }\end{array}$ & 2.8 & $\begin{array}{l}\text { Fire Preven- } \\
\text { tion \& Protec- } \\
\text { tion }\end{array}$ & 3.3 & $\begin{array}{l}\text { Air-condition- } \\
\text { ing \& Ventilation }\end{array}$ & 2.9 \\
\hline 14 & $\begin{array}{l}\text { Toilet Sani- } \\
\text { tary \& Fittings }\end{array}$ & 2.6 & $\begin{array}{l}\text { Fire Preven- } \\
\text { tion \& Protec- } \\
\text { tion }\end{array}$ & 2.6 & $\begin{array}{l}\text { Responsible } \\
\text { Management \& } \\
\text { Maintenance } \\
\text { Team }\end{array}$ & 3.0 & $\begin{array}{l}\text { Electrical Sys- } \\
\text { tem \& Provision }\end{array}$ & 2.8 \\
\hline 15 & $\begin{array}{l}\text { Electrical Sys- } \\
\text { tem \& Provision }\end{array}$ & 2.6 & $\begin{array}{l}\text { Security and Ac- } \\
\text { cess Control }\end{array}$ & 2.3 & $\begin{array}{l}\text { Electrical Sys- } \\
\text { tem \& Provision }\end{array}$ & 2.8 & $\begin{array}{l}\text { Safety Policies \& } \\
\text { Procedures }\end{array}$ & 2.7 \\
\hline 16 & $\begin{array}{l}\text { Passenger Lifts } \\
\text { Performance \& } \\
\text { Control }\end{array}$ & 2.6 & $\begin{array}{l}\text { Electrical Sys- } \\
\text { tem \& Provision }\end{array}$ & 2.3 & $\begin{array}{l}\text { Car Park Provi- } \\
\text { sion \& Acces- } \\
\text { sibility }\end{array}$ & 2.7 & $\begin{array}{l}\text { Car park Provi- } \\
\text { sion \& Accessi- } \\
\text { bility }\end{array}$ & 2.7 \\
\hline 17 & $\begin{array}{l}\text { Safety Poli- } \\
\text { cies \& Proce- } \\
\text { dures }\end{array}$ & 2.5 & $\begin{array}{l}\text { Air-condition- } \\
\text { ing \& Ventila- } \\
\text { tion }\end{array}$ & 2.2 & $\begin{array}{l}\text { Building Auto- } \\
\text { mation \& EMS }\end{array}$ & 2.4 & Branding/Image & 2.6 \\
\hline 18 & $\begin{array}{l}\text { Car Park Provi- } \\
\text { sion \& Acces- } \\
\text { sibility }\end{array}$ & 2.5 & $\begin{array}{l}\text { Modern IT \& } \\
\text { Telecommunica- } \\
\text { tion }\end{array}$ & 2.2 & $\begin{array}{l}\text { Security \& Ac- } \\
\text { cess Control }\end{array}$ & 2.4 & $\begin{array}{l}\text { Responsible Man- } \\
\text { agement \& Main- } \\
\text { tenance team }\end{array}$ & 2.6 \\
\hline 19 & $\begin{array}{l}\text { Air-condition- } \\
\text { ing \& Ventila- } \\
\text { tion }\end{array}$ & 2.4 & $\begin{array}{l}\text { Car Park Provi- } \\
\text { sion \& Acces- } \\
\text { sibility }\end{array}$ & 2.1 & $\begin{array}{l}\text { Air-condition- } \\
\text { ing \& Ventila- } \\
\text { tion }\end{array}$ & 2.3 & $\begin{array}{l}\text { Building Auto- } \\
\text { mation \& EMS }\end{array}$ & 2.5 \\
\hline 20 & $\begin{array}{l}\text { Security \& Ac- } \\
\text { cess Control }\end{array}$ & 2.3 & $\begin{array}{l}\text { Toilet Sani- } \\
\text { tary \& Fittings }\end{array}$ & 2.0 & $\begin{array}{l}\text { Passenger Lifts } \\
\text { Performance \& } \\
\text { Control }\end{array}$ & 2.2 & $\begin{array}{l}\text { Control of Build- } \\
\text { ing Services }\end{array}$ & 2.4 \\
\hline 21 & $\begin{array}{l}\text { Maintenance } \\
\text { Policy }\end{array}$ & 2.3 & $\begin{array}{l}\text { Passenger Lifts } \\
\text { Performance \& } \\
\text { Control }\end{array}$ & 2.0 & $\begin{array}{l}\text { Building Way- } \\
\text { finding }\end{array}$ & 2.1 & $\begin{array}{l}\text { Building Way- } \\
\text { finding }\end{array}$ & 2.3 \\
\hline 22 & $\begin{array}{l}\text { Building Auto- } \\
\text { mation \& EMS }\end{array}$ & 2.2 & $\begin{array}{l}\text { Cleaning/House- } \\
\text { keeping }\end{array}$ & 1.6 & $\begin{array}{l}\text { Control of Build- } \\
\text { ing Services }\end{array}$ & 2.1 & $\begin{array}{l}\text { After Hours Op- } \\
\text { erations }\end{array}$ & 2.3 \\
\hline 23 & $\begin{array}{l}\text { Control of } \\
\text { Building Ser- } \\
\text { vices }\end{array}$ & 2.1 & $\begin{array}{l}\text { Control of } \\
\text { Building Ser- } \\
\text { vices }\end{array}$ & 1.7 & $\begin{array}{l}\text { Safety Poli- } \\
\text { cies \& Proce- } \\
\text { dures }\end{array}$ & 1.9 & $\begin{array}{l}\text { Security \& Ac- } \\
\text { cess Control }\end{array}$ & 2.1 \\
\hline 24 & $\begin{array}{l}\text { Building Way- } \\
\text { finding }\end{array}$ & 1.9 & $\begin{array}{l}\text { Building Auto- } \\
\text { mation \& EMS }\end{array}$ & 1.6 & $\begin{array}{l}\text { After Hours } \\
\text { Operations }\end{array}$ & 1.7 & $\begin{array}{l}\text { Maintenance } \\
\text { Policy }\end{array}$ & 2.0 \\
\hline 25 & $\begin{array}{l}\text { After Hours Op- } \\
\text { erations }\end{array}$ & 1.8 & $\begin{array}{l}\text { After Hours Op- } \\
\text { erations }\end{array}$ & 1.5 & $\begin{array}{l}\text { Maintenance } \\
\text { Policy }\end{array}$ & 1.6 & $\begin{array}{l}\text { Toilet Sanitary \& } \\
\text { Fittings }\end{array}$ & 1.9 \\
\hline 26 & $\begin{array}{l}\text { Cleaning/ } \\
\text { Housekeeping }\end{array}$ & 1.6 & $\begin{array}{l}\text { Building Way } \\
\text { finding }\end{array}$ & 1.5 & $\begin{array}{l}\text { Cleaning/ } \\
\text { Housekeeping }\end{array}$ & 1.5 & $\begin{array}{l}\text { Cleaning/ } \\
\text { Housekeeping }\end{array}$ & 1.6 \\
\hline & Total & 100 & Total & 100 & Total & 100 & Total & 100 \\
\hline
\end{tabular}




\section{Analysis of the preferences of office space by the three main sectors}

The findings from the AHP analysis show the following observations on the selection of the subcriteria under the four main categories of Location, Lease, Building and Financial/Cost. From the selection of important "Location" sub-criteria, with the "level of crime" scoring the highest weight and "access to market" the lowest weight, it can be concluded that the preference for agglomeration factors has decreased for the three sector groups. The findings reveal that the groups differ from the findings for all tenants (as conducted in an earlier study) where "image" and "access to amenities" were ranked as more important than the "level of crime" (Adnan et. al. 2012). In this regard, the earlier studies by Sing et al. (2006) and Coffey and Shearmur (2002) which have considered the significance of the commercial centre for agglomeration, seem to have less significance for the choice of office space by the three sectors in the city centre of Kuala Lumpur. The advent of ICT may reduce the need for agglomeration (as highlighted by Gibson and Lizieri 2001; Sing 2005). This finding, however, challenges the proposition by Bollinger et al. (1998) that ICT could reduce information cost but could not replace the face-to-face interaction. "Accessibility to the market" is still an important criterion in office preference for these tenants' groups. This preference is also reflected by the preference of tenants for "access to public transportation \& terminal", which emerged as the second highest weight after the "level of crime".

The sub-criteria under "Lease" have almost equal weights, reflecting similarity of concern over the levels of occupation cost and security of tenure. The sub-criteria under "Building" that emerged as having the three highest weights are "responsible management \& maintenance", "modern IT \& telecommunication" and "fire prevention $\&$ protection". These sub-critera cover the aspects of management and services as mentioned in Babcock (2003), Ho et al. (2005) and Adnan et al. (2012). This can be viewed as the increasing need for better services and infrastructure, especially to accommodate for the higher specifications for IT \& communication needs by the three sectors' tenants. In meeting the business environment of these service-driven sectors, sophisticated needs will have to be met. These selections seem to be similar to the important factors that were chosen by all tenants as highlighted by Adnan et al. (2012). The criterion that was given the highest weight under "Financial/Cost" is "rental rate". Thus, this find- ing reflects the earlier studies by Dow and Porter (2004) and Gibson (2000), which emphasised the importance of financial factors, particularly ones related to cost of occupancy such as rental rate. This aspect is also shown to be significant as it was the overall choice by the three sectors for the sub-criteria with the highest global weights i.e. "rental rate" and "total occupancy cost".

For the overall standing of all the criteria that have been ranked by the three sectors' tenants according to global weights, the sub-criteria under the "Financial" criteria was ranked $1^{\text {st }}, 2^{\text {nd }}$ and $8^{\text {th }}$. On the other hand, the "Location" sub-criteria were ranked $3^{\text {rd }}, 4^{\text {th }}, 5^{\text {th }}, 6^{\text {th }}$ and $7^{\text {th }}$; accounting for the top eight of the top ten sub-criteria. The other two sub-criteria are within the "Lease" criteria. No "Building" sub-criteria were ranked in the top ten places. These findings are somehow different from the earlier finding of the tenants' survey conducted earlier (Adnan et al. 2012). The "Building" factors seem to be ranked with the highest Importance Index score. Apparently, the preference of all the combined sectors in the "Building" criteria is different from the three sectors' groups, which have placed lesser preference on these factors.

\section{Three-sector comparison}

When a general comparison is made between the three sector groups on the main criteria, there is a different preference for the top criteria between them. The Finance/Banking sector has chosen the "Financial/Cost" criterion, unlike the other two sectors, which have chosen "Location". There seems to be a varying preference for the lowest preferred criteria. Both the Oil \& Gas and Finance/ Banking sectors have placed the lowest weight on the "Building" criterion, whereas the ICT \& Media sector has placed the "Lease" terms as the lowest.

When comparing individual sectors, the various differences of the weights being placed on each of the sub-criteria under each category can be observed. There are varying preferences portrayed by the three sectors on each of the criteria. For "Location", the Finance sector has placed the highest weight on "image/branding", while the ICT \& Media has placed "level of criminal rate" as the highest. The oil and gas sector has placed "accessibility to public transportation \& terminal" as the highest. The findings reflect the nature of business of each sector which value different criteria and sub-criteria, an observation which was highlighted by Sing et al. (2004). It is possible that the finance sector in the central location values the locational 
prestige, as stated by Dent and White (1998) and Niemi and Lindholm (2010). As for the ICT \& Media sector, the preference for level of criminal rate might reflect concern for the security of its operations, which may extend after hours. As for the Oil and Gas sector, preference for public transportation \& terminal verifies the accessibility need, as confirmed by earlier studies by Sing et al. (2006).

As for the "Lease" criteria, only the Finance sector has placed "payment of monies" higher than "termination clause". Both the ICT \& Media and Oil \& Gas have placed "termination clause" with the higher percentage. This reflects their concerns regarding the monetary arrangement of payment to meet their operation. On the other hand, the other two sectors are more concerned with the security of tenure of the space. As for the "Building" criteria, the Finance sector has placed "responsible management \& maintenance" team as the top building sub-criteria. The ICT \& Media Sector has placed "modern IT \& telecommunication systems" with the highest weight, while the Oil and Gas sector has placed "passenger lift performance \& capacity" highest. The preferences for the "Building" sub-criteria reflect the nature of the operations whereby each of the sectors has a different focus, especially the ICT \& Media sector which requires up-to-date ICT infrastructure and facilities in order to operate. Finally, when assessing the local weights of the "Finance" sub-criteria for the three sectors, all of them have placed "rental rate" with the highest weight and the "cost of fit out" with the lowest weight.

What can be observed from the comparison of the three sectors is the preference of each sector over the choice of the highest and lowest weight and rank among the criteria and sub-criteria. Thus, findings confirm the work of Leishman and Watkins (2004) and Sing et al. (2004) that office occupation decisions are made in different ways and also depend on various factors, which include types of organisations, size and structure. Niemi and Lindholm (2010) had earlier highlighted the importance of capturing the best method to gauge occupiers' needs, as currently there is a changing working practice from an organisation's operations perspective.

Capturing a tenant's preference towards the identified office attributes is the main indicator that reflects the preference of a consumer towards a product. As such the use of AHP has certainly provided the means to achieve this. The identification of the relative weights through the use of
AHP has examined tenants' perspectives with regard to their preferred office space within the city centre of Kuala Lumpur. As an approach, AHP has proven its ability to reveal a customer's preference in this study by revealing the preferences of the three main tenant sectors of the office buildings in Kuala Lumpur.

\section{CONCLUSIONS}

Earlier studies have propositioned that tenant profiles exert an influence on office occupation preferences, such that different profiles have differing preferences over factors in the decision making process. The onus of the current study has been to clarify those differences. What has been uncovered from the findings shows the various differences in preferences of the office space decision making among tenants. When the three sectors are compared, each has shown different preferences for the important sub-criteria at varying weights. Apparently, the largest weights are given to "Financial" and "Location". It has been shown that when a comparison of preferences of the sub-criteria is made between two sectors at a time, the correlations are generally high. The ICT \& Media sector has shown to be giving less priority to "Location" in the office occupation decision making. On the other hand, the Oil \& Gas sector displays a higher preference for "Building" than the other two sectors, as well as a higher preference for "Location" compared to ICT \& Media sector.

The above findings reveal that while considering the preferences of the main tenant sectors of top-grade office buildings in Kuala Lumpur's city centre, it is worth acknowledging the differences amongst them. Given the various different features and attributes that office buildings may offer as a product, managers or owners ought to consider the various preferences tenants have in considering what changes to be made. This will ensure they attract their ideal tenant types for their office buildings. The findings also benefit future office space providers who need to align their office provision to the preferences of the major tenants sectors in ways that would mitigate the impending oversupply of office space. What would be useful in deriving the relative importance of these factors among the major tenant sectors is to develop a tenant-office space suitability matrix. The matrix would match the different types of tenants with the existing attributes of the top-grade office buildings in the city centre of Kuala Lumpur, Malaysia. 


\section{REFERENCES}

Abel, J. 1994. What tenants want and what they will not compromise on when looking for new premises:considerations influencing relocation, Property Management 12(1): 28-30. http://dx.doi. org/10.1108/02637479410052299

Adnan, Y. M.; Daud, M. N.; Razali, M. N. 2012. Property specific criteria for office occupation by tenants of purpose built office buildings in Kuala Lumpur, Malaysia, Property Management 30(2): 114-128. http:// dx.doi.org/10.1108/02637471211213389

Adnan, Y. M.; Daud, M. N. 2010. Factors influencing office building occupation decision by tenants in Kuala Lumpur city centre - a Delphi Study, Journal of Design and Built Environment 6: 63-82.

Anderson, D.; Sweeney, D. J.; Williams, T. A. 2005. An introduction to management science. Quantitative approaches to decision making. South Western Ohio: Thomson.

Argote, L.; Greve, H. R. 2007. A behavioral theory of the firm - 40 years and counting: Introduction and impact, Organization Science 18(3): 337-349. http:// dx.doi.org/10.1287/orsc.1070.0280

Babcock, R. R. 2003. The tenant/workplace equation I, Buildings 91(1): 50-52.

Bollinger, R. C.; Ihlandfeldt, K. R.; Bowes, R. D. 1998. Spatial variation in office rents within Atlanta region, Urban Studies 35(7): 1097-1118. http://dx.doi. org/10.1080/0042098984501

Cheng, E. W.; Li, H. 2002. Construction partnering process and associated critical success factors: quantitative investigation, Journal of Management in Engineering 18(4): 194-202. http://dx.doi.org/10.1061/ (ASCE)0742-597X(2002)18:4(194)

Chua, Y. P. 2006. Kaedah dan statistik penyelidikan asas statistik penyelidikan buku 2. s.l. McGraw-Hill (Malaysia) Sdn Bhd.

Coffey, W.; Shearmur, R. 2002. Agglomeration and dispersion of high order service employment in the Montreal metropolitan region, 198196, Urban Studies 39: 359-378. http://dx.doi. org/10.1080/00420980220112739

Dent, P.; White, A. 1998. Corporate real estate: changing office occupier needs - a case study, Facilities 16(9/10): 262-270. http://dx.doi. org/10.1108/02632779810229084

Dow, J. M.; Porter, G. A. 2004. Restructuring and renewing existing leases in today's commercial office market: guidelines for tenants to evaluate options and negotiate terms, Journal of Corporate Real Estate 6(3): 237-242. http://dx.doi. org/10.1108/14630010410812360

Dunse, N.; Jones, C. 1998. A hedonic price model of office rents, Journal of Property Valuation and Investment 16(3): 297-312. http://dx.doi. org/10.1108/14635789810221760

Dunse, N. A.; Jones, C. 2002. The existence of office submarkets in cities, Journal of Property Research 19(2): 1-24. http://dx.doi.org/10.1080/09599910210125214

Dunse, N. A.; Leishman, C.; Watkins, C. 2001. Classifying office submarkets, Journal of Property In- vestments \& Finance 19(3): 236-250. http://dx.doi. org/10.1108/14635780110387592

Forman, E. H.; Gass, S. I. 2001. The analytic hierarchy process: an exposition, Operations Research 49(4): 469-486. http://dx.doi.org/10.1287/ opre.49.4.469.11231

Forman, E. H.; Selly, M. A. 2000. Decision by objectives. Pittsburg, USA: Expert Choice Inc.

Gibson, V.; Lizieri, C. 2001. Friction and inertia: business change, corporate real estate portfolios and the UK office market, Journal of Real Estate Research 22(1): 29-79. http://dx.doi.org/10.1108/02632770010315715

Gibson, V. 2000. Property portfolio dynamics: the flexible management of the unflexible assets, Facilities 18(3/4): 150-154. http://dx.doi. org/10.1108/02632770010315715

Helm, R.; Scholl, A.; Manthey, L.; Steiner, M. 2004. Measuring customer preferences in new product development: comparing compositional and decompositional methods, International Journal of Product Development 1(1): 12-29. http://dx.doi.org/10.1504/ IJPD.2004.004888

Helm, R.; Steiner, M.; Scholl, A.; Manthey, L. 2008. A comparative empirical study on common methods for measuring preferences, International Journal of Management and Decision Making 9(3): 242-265. http://dx.doi.org/10.1504/IJPD.2004.004888

Ho, D.; Newell, G.; Walker, A. 2005. The importance of property-specific attributes in assessing CBD office building quality, Journal of Property Investment \& Finance 23(5): 424-444. http://dx.doi. org/10.1108/14635780510616025

Kauko, T. 2003. Residential property value and location externalities, Journal of Property Investment and Finance 21(3): 250-270. http://dx.doi.org/10.1007/ s10901-006-9040-y

Kauko, T. 2006. What makes a location attractive for housing consumer? Preliminary findings from Metropolitan Helsinki and Randstad, Holland, using analytical hierarchy process, Journal of Housing and the Built Environment 21(2): 159-176. http://dx.doi. org/10.1007/s10901-006-9040-y

Kauko, T. 2007. An analysis of housing location attributes in the inner city of Budapest, Hungary, using expert judgements, International Journal of Strategic Property Management 11(4): 209-225. http:// dx.doi.org/10.1080/1648715X.2007.9637570

Koo, H. Y.; Koo, L. C. 2010. Empirical examination of AHP and Conjoint Analysis on casino attributes in Macau, in Proceedings of International Conference on Public Welfare and Gaming Industry, 9-11 December 2010, Beijing, 327-350.

Kuala Lumpur Structure Plan 2020. (n.d.). Kuala Lumpur City Hall. Available at: http://www.dbkl.gov. my/pskl2020 [accessed 30 January 2011]

Leishman, C.; Allison, O.; Giuseppe, P. 2012. The impact of carbon emission reducing design features on office occupiers' choice of premises, $U r$ ban Studies 49(11): 2419-2437. http://dx.doi. org/10.1177/0042098011427189

Leishman, C.; Watkins, C. 2004. The decision making behavior of office occupiers, Journal of Property 
Investment and Finance 22(4): 307-319. http://dx.doi. org/10.1108/14635780410550876

Li, L. H. 2009. Community attachment and housing choice in Hong Kong, Property Management 27(1): 42-57. http://dx.doi.org/10.1108/02637470910932665

Malaysia Standard Industrial Classification (MSIC). 2008. Malaysia: Statistics Department.

March, J. G.; Simon, H. G. 1958. Organisations. New York: Wiley.

Mills, E. S. 1992. Office rent determinants in the Chicago area, Real Estate Economics 20(2): 273-287. http://dx.doi.org/10.1111/1540-6229.00584

NAPIC. 2013. Property market report quarter 2012. Malaysia: Department of Valuation \& Property Services, Ministry of Finance, Malaysia.

Newell, G.; Seabrook, R. 2006. Factors influencing hotel investment decision making, Journal of Property Investment and Finance 24(4): 279-294. http://dx.doi. org/10.1108/14635780610674499

Niemi, J.; Lindholm, A. L. 2010. Methods for evaluating office occupier's needs and preference, Journal of Corporate Real Estate 12(1): 33-46. http://dx.doi. org/10.1108/14630011011025906

Olawande, O. A. 2011. Harnessing real estate investment through proper tenant selection in Nigeria, Property Management 29(4): 383-397. http://dx.doi. org/10.1108/02637471111154827

Saaty, T. L. 1980. The analytic hierarchy process. New York: McGraw-Hill.

Saaty, T. L. 1990. How to make a decision, the analytic hierarchy process, Journal of Operational
Research 48: 9-26. http://dx.doi.org/10.1016/03772217(90)90057-I

Saaty, T. L. 1994. How to make a decision, the analytic hierarchy process, Interfaces 24(6): 19-43. http:// dx.doi.org/10.1287/inte.24.6.19

Saaty, T. L.; Vargas, L. G. 2012. Models, methods, concepts \& applications of the analytic hierarchy process, 175. New York: Springer. http://dx.doi. org/10.1007/978-1-4614-3597-6

Sing, T. F. 2005. Impact of information and communication technology on real estate space: perspective of office occupiers, Journal of Property Investment \& Finance 23(6): 494-505. http://dx.doi. org/10.1108/14635780510626538

Sing, T. F.; Ooi, J. T. L.; Lum, A. L. 2004. Influence of occupiers' characteristics in office space decision, $R e$ search working paper. Available at: www.rst.edu.sg/ research/working paper/2005-004 [accessed 20 September 2008]

Sing, T. F.; Ooi, J. T. L.; Wong, A. L.; Lum, P. L. L. 2006. Network connectivity and office occupiers' space decision: the case of Suntec city, Journal of Property Investment and Finance 24(3): 221-238. http://dx.doi. org/10.1108/14635780610659937

WTW Property Market Report. 2011. CH Williams Talhar Wong Sdn Bhd. Kuala Lumpur.

Wu, F. 2010. Housing environment preference of young consumers in Guangzhou, China: using the analytic hierarchy process, Property Management 28(3): 174192. http://dx.doi.org/10.1108/02637471011051318 